JIEB (ISSN : 2442-4560) available online at : ejournal.stiepancasetia.ac.id

\title{
PENGARUH FAKTOR PENDIDIKAN, UMUR DAN PENGALAMAN \\ KERJA TERHADAP KINERJA APARATUR SIPIL NEGARA (ASN) \\ PADA DINAS PEKERJAAN UMUM PENATA RUANG, PERUMAHAN \\ DAN KAWASAN PERMUKIMAN KABUPATEN KAPUAS \\ KALIMANTAN TENGAH
}

\section{Leonshen Hasudungan}

Dinas Pekerjaan Umum, Penataan Ruang, Perumahan dan Kawasan Permukiman Kabupaten Kapuas

Jl. Tambun Bungai No. 29 Selat Hilir Kec. Selat, Kabupaten Kapuas, Kalimantan Tengah

e-mail: leonshenhas@gmail.com

\begin{abstract}
This study aims to identify and analyze the influence of education, age and work experience simultaneously and partially on the performance of the civilian state apparatus. The research design used in this study is Eksplanatory which intends to explain the causality relationship between the dependent variable with independent variables which the model analysis approach used is multiple linear regression analysis. The results showed that education, age, and working experience simultaneously influence apparatus performance, while partially only working experience had a significant influence to performance.
\end{abstract}

Keywords: education, age, work experience, performance.

Abstrak: Penelitian ini bertujuan untuk mengetahui dan menganalisa pengaruh faktor pendidikan, umur dan pengalaman kerja secara simultan dan parsial terhadap kinerja aparatur sipil negara. Rancangan penelitian yang digunakan dalam penelitian ini adalah Eksplanatory yang bermaksud untuk menjelaskan hubungan kasualitas antara variabel terikat dengan variabel-variabel bebasnya dimana model pendekatan analisis yang digunakan adalah analisis regresi linier berganda. Hasil penelitian menunjukan bahwa faktor pendidikan, umur dan pengalaman kerja berpengaruh signifikan terhadap kinerja aparatur negara, tetapi hanya pengalaman kerja yang berpengaruh signifikan terhadap kinerja.

Kata Kunci: pendidikan, umur, pengalaman kerja dan kinerja.

\section{Latar Belakang}

Perkembangan birokrasi yang pesat dewasa ini menuntut proses pengelolaan sumber daya dalam organisasi dapat terlaksana dengan baik, sumber daya manusia yang berkualitas merupakan kunci dalam reformasi birokrasi, karena sumber daya tersebut merupakan faktor penggerak utama dalam mencapai tujuan organisasi. Penggerak utama dalam mencapai tujuan organisasi, berhasil tidaknya suatu organisasi menjaga eksistensinya sangat tergantung kepada kondisi kualitas SDM yang dimiliki, oleh karena itu dalam proses rekrutmen pegawai harus dilaksanakan dengan baik dan benar sesuai dengan prosedur dan aturan yang berlaku.

Suwanto (2011: 63) menyatakan bahwa rekrutmen sebagai proses untuk mendapatkan jumlah SDM (pegawai) yang berkualitas untuk menduduki suatu jabatan atau pekerjaan dalam suatu instansi. Proses rekrutmen pegawai adalah bagian dari kondisi SDM pegawai, sehingga perlu diidentifikasi prosesnya karena tidak supply dan demand serta penyesuaian mengenai rekrutmen dan sebelumnya dilihat sebagai alasan tujuanya. Berhasil tidaknya suatu instansi dalam mempertahankan eksitensi instansi dimulai dari manusia itu sendiri 
dalam meningkatkan efektivitas dan efisiensi secara maksimal. Mengangkat pegawai merupakan faktor yang terpenting dalam pelaksanaan proses birokrasi maka diperlukan pegawai yang mempunyai keterampilan dan keahlian demi kelangsungan hidup instansi. Kondisi sumber daya manusia Dinas Pekerjaan Umum penata ruang perumahan dan kawasan pemukiman Kabupaten Kapuas Kalimantan Tengah terbentuk berdasarkan Peraturan Bupati Nomor 13 Tahun 2008 adalah merupakan Susunan Kelembagaan dari Dinas Pekerjaan Umum penata ruang perumahan dan kawasan pemukiman Kabupaten Kapuas Kalimantan Tengah sebagai tindak lanjut pelaksanaan otonomi daerah yang merupakan langkahlangkah penguatan kewenangan, efisiensi, efektifitas, akuntabilitas kinerja kelembagaan, peningkatan kualitas sumber daya manusia serta informasi manajemen yang akurat dan praktis.

Kualitas dari tenaga kerja dapat dilihat dari tingkat pendidikan dan pelayanan instansi terhadap pegawai. Pendidikan yang dimiliki seseorang akan mempengaruhi produktivitas kerjanya. Karena dengan pendidikan inilah seseorang memiliki modal untuk melakukan produktivitas di dalam suatu pekerjaan. Kondisi ini didukung oleh kurang meratanya kesempatan bagi sebagian penduduk dalam mengakses pendidikan. Padahal pendidikan merupakan salah satu hal yang memampukan masyarakat bersaing dalam dunia kerja, karena diharapkan dengan semakin tinggi pendidikan seseorang, maka produktivitas orang tersebut juga semakin tinggi. Untuk meningkatkan produktivitas para tenaga kerja, maka diperlukan penghargaan serta pengakuan keberadaan para tenaga kerja tersebut.

Pendidikan dianggap sebagai sarana untuk mendapatkan sumber daya manusia yang berkualitas. Karena, pendidikan dianggap mampu untuk menghasilkan tenaga kerja yang bermutu tinggi, mempunyai pola pikir dan cara bertindak yang modern. Sumber daya manusia seperti inilah yang diharapkan mampu menggerakkan roda pembangunan ke depan. Salah satu upaya dalam mewujudkan relevansi pendidikan dengan kebutuhan pembangunan ini dikenal dengan kebijakan link and match. Kebijakan ini bertujuan untuk mengoptimalkan dan mengefisienkan sumber daya manusia dengan sistem pendidikan. Semakin selaras struktur tenaga kerja yang disediakan oleh sistem pendidikan dengan struktur lapangan kerja maka semakin efisienlah sistem pendidikan yang ada. Karena dalam pengalokasian sumber daya manusia akan diserap oleh lapangan kerja (Fadhilah Rahmawati, dkk, 2011).

Selanjutnya yang juga diperkirakan mempengaruhi produktivitas seseorang dalam bekerja adalah pengalaman kerja. Dengan tingkat pendidikan yang tinggi dan didukung adanya pengalaman kerja, maka tenaga kerja akan mempunyai lebih banyak kesempatan untuk mendapatkan pekerjaan. Diperkirakan bahwa dengan pengalaman kerja, calon pencari kerja lebih sanggup untuk mendapatkan pekerjaan yang sesuai dengan bidang yang pernah dialaminya. Saat seorang pekerja memiliki pekerjaan sesuai dengan pengalaman kerja dan keahliannya, pekerja tersebut dapat memaksimalkan pengetahuan dan skillnya sehingga meningkatkan input dan produktivitasnya (Amron, 2010) Selain itu usia juga diperkirakan mempengaruhi produktivitas seseorang dalam bekerja. Usia tenaga kerja cukup menentukan keberhasilan dalam melakukan suatu pekerjaan, baik sifatnya fisik maupun non fisik. Pada umumnya, tenaga kerja yang berumur tua mempunyai tenaga fisik yang lemah dan terbatas, sebaliknya tenaga kerja yang berumur muda mempunyai kemampuan fisik yang kuat (Amron, 2010). Menurut Badan Pusat Statistik penduduk yang berpotensi sebagai modal dalam pembangunan yaitu penduduk usia produktif atau yang berusia 15-64 tahun.

\section{Studi Literatur}

Menurut Andrew E. Sikula dalam Mangkunegara (2003:50) tingkat pendidikan adalah suatu proses jangka panjang yang menggunakan prosedur sistematis dan terorganisir, yang mana tenaga kerja manajerial mempelajari pengetahuan konseptual dan teoritis untuk tujuan-tujuan umum. Dengan demikian Hariandja (2002: 169) menyatakan bahwa tingkat pendidikan 
seorang karyawan dapat meningkatkan daya saing perusahaan dan memperbaiki kinerja perusahaan.

Tingkat pendidikan adalah tahapan pendidikan yang ditetapkan berdasarkan tingkat perkembangan peserta didik, tujuan yang akan dicapai dan kemauan yang dikembangkan. Tingkat pendidikan berpengaruh terhadap perubahan sikap dan perilaku hidup sehat. Tingkat pendidikan yang lebih tinggi akan memudahkan sesorang atau masyarakat untuk menyerap informasi dan mengimplementasikannya dalam perilaku dan gaya hidup sehari-hari, khususnya dalam hal kesehatan. Pendidikan formal membentuk nilai bagi seseorang terutama dalam menerima hal baru (Suhardjo, 2007).

Istilah usia diartikan dengan lamanya keberadaan seseorang diukur dalam satuan waktu di pandang dari segi kronologik, individu normal yang memperlihatkan derajat perkembangan anatomis dan fisiologik sama (Nuswantari, 1998). Usia adalah lama waktu hidup atau ada (sejak dilahirkan atau diadakan) (Hoetomo, 2005). Sedangkan usia ibu hamil adalah usia ibu yang diperoleh melalui pengisian kuesioner. Penyebab kematian maternal dari faktor reproduksi diantaranya adalah maternal age/usia ibu. Dalam kurun reproduksi sehat dikenal bahwa usia aman untuk kehamilan dan persalinan adalah 20-30 tahun. Kematian maternal pada wanita hamil dan melahirkan pada usia di bawah 20 tahun ternyata 2 sampai 5 kali lebih tinggi dari pada kematian maternal yang terjadi pada usia 20 sampai 29 tahun. Kematian maternal meningkat kembali sesudah usia 30 sampai 35 tahun (Sarwono, 2008). Usia seorang wanita pada saat hamil sebaiknya tidak terlalu muda dan tidak terlalu tua. Umur yang kurang dari 20 tahun atau lebih dari 35 tahun, berisiko tinggi untuk melahirkan. Kesiapan seorang perempuan untuk hamil harus siap fisik, emosi psikologi, sosial dan ekonomi (Ruswana, 2006).

Pengalaman kerja adalah proses pembentukan pengetahuan atau keterampilan tentang metode suatu pekerjaan karena keterlibatan karyawan tersebut dalam pelaksanaan tugas pekerjaan (Manulang, 1984 : 15). Pengalaman kerja adalah ukuran tentang lama waktu atau masa kerja yang telah ditempuh seseorang dapat memahami tugas - tugas suatu pekerjaan dan telah melaksanakan dengan baik (Ranupandojo, 1984 : 71)

Pengalaman kerja pada pekerjaan sejenis, perlu mendapatkan pertimbangan dalam penempatan tenaga kerja. Kenyataan menunjukkan makin lama tenaga kerja bekerja, makin banyak pengalaman yang dimiliki tenaga kerja yang bersangkutan. Sebaliknya, makin singkat masa kerja, makin sedikit pengalaman yang diperoleh. Pengalaman bekerja banyak memberikan keahlian dan keterampilan kerja. Sebaliknya, terbatasnya pengalaman kerja mengakibatkan tingkat keahlian dan keterampilan yang dimiliki makin rendah. Pengalaman bekerja yang dimiliki seseorang, kadang - kadang lebih dihargai dari pada tingkat pendidikan yang menjulang tinggi.

Kinerja adalah segala hasil capaian dari segala bentuk tindakan dan kebijakan dalam rangkaian usaha kerja pada jangka waktu tertentu guna mencapai suatu tujuan. Sebuah jawaban untuk pertanyaan dalam definisi kinerja menurut Robbin dalam Nawawi (2006: 62), yakni kinerja adalah jawaban atas pertanyaan "apa hasil yang dicapai seseorang sesudah mengerjakan sesuatu."

Mangkunegara (2000: 67) mengatakan bahwa kinerja pegawai adalah hasil kerja secara kualitas dan kuantitas yang dicapai oleh seseorang pegawai dalam melaksanakan tugasnya sesuai dengan tanggungjawab yang diberikan kepadanya. Perhatian terhadap kinerja merupakan suatu hal yang perlu bagi sebuah organisasi ataupun perusahaan. Kinerja bukan hanya sekedar mencapai hasil tapi secara luas perlu memperhatikan aspekaspek lain, sebagaimana definisi kinerja menurut Prawirosentono (2008)

Kinerja adalah segala hasil capaian dari segala bentuk tindakan dan kebijakan dalam rangkaian usaha kerja pada jangka waktu tertentu guna mencapai suatu tujuan. Sebuah jawaban untuk pertanyaan dalam definisi kinerja menurut Robbin dalam Nawawi (2006: 62), yakni kinerja adalah jawaban atas pertanyaan "apa hasil yang dicapai seseorang sesudah mengerjakan sesuatu." Mangkunegara (2000: 67) mengatakan 
bahwa kinerja pegawai adalah hasil kerja secara kualitas dan kuantitas yang dicapai oleh seseorang pegawai dalam melaksanakan tugasnya sesuai dengan tanggungjawab yang diberikan kepadanya. Perhatian terhadap kinerja merupakan suatu hal yang perlu bagi sebuah organisasi ataupun perusahaan. Kinerja bukan hanya sekedar mencapai hasil tapi secara luas perlu memperhatikan aspekaspek lain, sebagaimana definisi kinerja menurut Prawirosentono (2008), kinerja (performance) adalah hasil kerja yang dapat dicapai oleh seseorang atau sekelompok orang dalam suatu organisasi, sesuai dengan wewenang dan tanggung jawab masingmasing, dalam rangka upaya mencapai tujuan organisasi bersangkutan secara legal, tidak melanggar hukum dan sesuai dengan moral maupun etika. Terkhusus bagi lembaga publik, definisi kinerja yang demikian menjadi perhatian agar dapat menjalankan fungsi dan peran sesuai aturan dan menjadi teladan bagi lainnya. Dengan demikian, tidak akan ada tindakan-tindakan penyimpangan ketika setiap individu (pegawai) tidak melanggar hukum dan sesuai dengan moral maupun etika. Berdasarkan definisi-definisi yang ada, dapat disimpulkan bahwa kinerja pegawai merupakan hasil kerja yang dicapai pegawai dalam jangka waktu tertentu guna mencapai suatu tujuan.

Secara garis besar, kinerja dapat dipahami sebagai hasil kerja yang dapat dicapai oleh seseorang atau sekelompok orang dalam suatu organisasi sesuai dengan wewenang dan tanggung jawab masingmasing, guna mencapai tujuan organisasi yang bersangkutan secara legal, tidak melanggar hukum, dan sesuai dengan moral maupun etika. Waldman (2013) mendefinisikan kinerja sebagai gabungan perilaku dengan prestasi dari apa yang diharapkan dan pilihannya atau bagian syarat-syarat tugas yang ada pada masingmasing individu dalam organisasi. Sedangkan menurut Mangkunegara (2011); kinerja dapat didefinisikan sebagai hasil kerja secara kualitas dan kuantitas yang dapat dicapai oleh seorang pegawai dalam melaksanakan tugas sesuai dengan tanggungjawab yang diberikan kepadanya. Cascio (2011) dalam Koesmono (2012) mengatakan bahwa kinerja merupakan prestasi karyawan dari tugas-tugas yang telah ditetapkan. mengatakan bahwa kinerja merupakan hasil pekerjaan seorang karyawan selama periode tertentu dibandingkan dengan berbagai kemungkinan, seperti standar, target/sasaran maupun kriteria yang telah ditentukan terlebih dahulu dan telah disepakati bersama.

Bernadin dan Russel

mendefinisikan kinerja sebagai catatan keberhasilan yang dihasilkan dari fungsi suatu pekerjaan tertentu atau kegiatan selama kurun waktu tertentu. Whitmore (2012) mengemukakan bahwa "kinerja" dengan asal kata "kerja" berarti aktivitas yang dilakukan oleh seseorang atau organisasi dalam menjalankan tugas yang menjadi pekerjaannya. Kinerja merupakan suatu perbuatan, suatu prestasi, atau penampilan umum dari keterampilan. Mangkunegara (2011), mengatakan bahwa istilah kinerja berasal dari kata job performance atau actual performance, yaitu unjuk kerja atau prestasi yang sesungguhnya dicapai oleh seseorang dalam melaksanakan tugas sesuai dengan tanggung jawab yang diberikan kepadanya.

Seseorang akan selalu mendambakan penghargaan terhadap hasil pekerjaannya dan mengharapkan imbalan yang adil. Penilaian kinerja perlu dilakukan seobyektif mungkin karena akan memotivasi karyawan dalam melakukan kegiatannya. Di samping itu, penilaian kinerja dapat memberikan informasi untuk kepentingan pemberian gaji, promosi dan pengawasan terhadap perilaku karyawan. bahwa penilaian kinerja (performance appraisals) merupakan suatu sistem yang digunakan untuk menilai dan mengetahui sejauh mana karyawan telah melaksanakan pekerjaannya masing-masing secara keseluruhan.

\section{Metode Penelitian}

Sesuai dengan masalah dan tujuan yang dirumuskan, penelitian ini bermaksud untuk menejlaskan hubungan kasualitas antara variabel terikat dengan variabel-variabel bebasnya. Sehubungan dengan tujuan tersebut, penelitian ini merupakan penelitian explanatory reseach, adapun model 
penedekatan analisis yang digunakan adalah analisis regresi liner berganda.

Jenis data yang digunakan pada penelitian ini adalah:

1. Kuantitatif, yaitu data yang berbentuk angka, atau data kualitatif yang diangkakan dalam bentuk skoring. Data kuantitatif yang digunakan dalam penelitian ini dalam bentuk skoring hasil jawaban responden.

2. Kualitatif, yaitu data yang dinyatakan dalam bentuk kata, kalimat, dan gambar. Data kualitatif yang digunakan dalam penelitian ini berupa teori - teori komitmen pegawai, kepemimpinan, Tesis, dll. Yang relevan dengan penelitian ini.

Sumber data yang digunakan dalam penelitian ini meliputi:

1. Data primer, yaitu data penelitian yang diperoleh secara langsung dari responden pegawai Dinas Pekerjaan Umum Kabupaten Kapuas Kalimantan Tengah yang dikumpulkan menggunakan kuesioner.

2. Data sekunder, yaitu data yang diperoleh secara tidak langsung, meliputi semua data yang berhubungan dengan kegiatan pada Dinas Pekerjaan Umum Kabupaten Kapuas Kalimantan Tengah, seperti gambaran umum Lembaga, sejarah, struktur organisasi, dan perkembanganpegawai.

Pada skala likert, beberapa pertanyaan diurutkan secara hierarkis untuk melihat sikap tertentu dari sederetan jawaban tersebut. Jadi skala likert adalah skala yang digunakan untuk jawaban yang bersikap jelas (tegas). Adapun teknik pengumpulan data dalam hasil penelitian ini yaitu sebagai berikut:

1. Kuesioner, yaitu dengan cara menyampaikan kuisioner kepada responden untuk mendapatkan data sesuai dengan tujuan penelitian. Jenis pertanyaan yang digunakan adalah pertanyaan yang bersifat tertutup. Dengan adanya dua pilihan alternatif yaitu ya atau tidak, responden diminta untuk memberikan tanggapan secara pribadi yang nantinya akan dianalisissesuai dengan hipotesis yang di ajukan.

2. Observasi, yaitu teknik pengumpulan data yang dilakukan dengan cara mengamati langsung ke obyek penelitian.

3. Wawancara, yaitu teknik pengumpulan data yang dilakukan dengan cara tanya jawab kepada pihak terkait di obyek penelitian.

4. Dokumentas dan Studi Pustaka, yaitu teknik pengumpulan data yang dilakukan dengan mempelajari literatur maupun dokumen dari obyek penelitian.

Serangkaian teknik analisis data yang digunakan dalam penelitian ini meliputi:

1. Uji Validitas. Digunakan untuk mengukur valid atau tidaknya suatu indikator. Suatu kuesioner dikatakan valid jika pernyataan kuesioner mampu untuk mengungkapkan sesuatu yang akan diukur oleh kuesioner tersebut. Dalam penelitian ini, pengujian validitas instrumen penelitian dilakukan dengan melihat angka signifikansi, yaitu membandingkan nilai $\mathrm{r}$ hitung (Corrected Item-Total Correlation) dengan $\mathrm{r}$ tabel untuk degree of freedom $(\mathrm{df})=\mathrm{n}-2$.

2. Uji Reliabilitas. Digunakan untuk mengukur kehandalan indikator. Jika angka reliabilitas Alpha Cronbach > 0.6 maka item variabel tersebut dinyatakan reliable, dan jika angka reliabilitas Alpha $<0.6$ maka item variabel tersebut dinyatakan tidak reliable (Nunnaly,2011).

3. Uji asumsi klasik. Terdiri dari uji multikolinearitas, uji heterokedastisitas, dan uji normalitas.

4. Uji $\mathrm{F}$ dan uji $\mathrm{t}$ untuk melihat pengaruh variabel bebas terhadap variabel terikat secara simultan dan parsial.

\section{Hasil Penelitian dan Pembahasan}

Langkah analisis yang dilakukan pertama adalah pengujian validitas dan reliabilitas instrumen penelitian. Suatu kuesioner dikatakan valid jika pertanyaan pada kuesioner tersebut mampu untuk mengungkap sesuatu yang akan diukur oleh kuesioner tersebut. Pengujian validitas pada penelitian ini dilakukan dengan cara menghitung korelasi skor masing-masing butir pertanyaan dengan skor total seluruh 
butir pertanyaan. Suatu butir pertanyaan adalah valid jika terdapat korelasi yang signifikan yang ditunjukkan dengan nilai signifikansi yang kurang dari nilai $\mathrm{a}=0,05$. Suatu instrumen juga dapat dikatakan reliabel jika memiliki nilai Cronbach's Alpha lebih dari 0,6. Karena pada penelitian ini semua indikator memiliki korelasi yang kuat dan signifikan dengan variabelnya, dan nilai cronbach's alpha masing-masing variabel daitas 0,6, maka dapat dikatakan bahwa instrumen yang digunakan dalam penelitian ini valid dan reliabel.

Langkah selanjutnya adalah uji asumsi klasik, yang dimulai dengan uji multikolinearitas. Uji multikolineritas bertujuan menguji apakah dalam model regresi ditemukan adanya korelasi antar variabel bebas model regresi yang baik seharusnya tidak terjadi korelasi diantara variabel bebas jika variabel bebas berkorelasi maka variabel-variabel ini tidak ortogonal. Variabel ortogonal adalah variabel bebas yang nilai korelasi antar sesama variabel bebas $=0$. Multikolineritas dapat dilihat dari nilai Tolerance dan Variance Inflation Factor (VIF). Menurut Imam Ghozali (2009), cara mendeteksi terhadap adanya multikolineritas dalam model regresi adalah sebagai berikut: Besarnya Variabel Inflation Factor (VIF), pedoman suatu model regresi yang bebas Multikolineritas yaitu nilai VIF $\leq$ 10.

Berdasarkan data pada tabel 1, karena nilai VIF nya kurang dari 10, maka penelitian ini dinyatakan bebas masalah multikolinearitas.

Langkah selanjutnya adalah uji heterokedastisitas. Dalam pengujian heteroskedastisitas digunakan untuk menguji apakah dalam model regresi terjadi ketidaksamaan variance dari residual satu pengamatan ke pangamatan lain. Suatu penelitian dinyatakan bebas masalah heterokedastisitas jika data pada scatterplot menyebar tidak beraturan. Untuk Lebih Jelas lihat Gambar 1.

Tabel 1. Uji Multikolinearitas

\begin{tabular}{|c|c|c|c|c|c|c|c|}
\hline \multicolumn{8}{|c|}{ Coefficients $^{\mathbf{a}}$} \\
\hline \multirow[t]{2}{*}{ Model } & \multicolumn{2}{|c|}{$\begin{array}{c}\text { Unstandardized } \\
\text { Coefficients }\end{array}$} & \multirow{2}{*}{$\begin{array}{c}\begin{array}{c}\text { Standardized } \\
\text { Coefficients }\end{array} \\
\text { Beta }\end{array}$} & \multirow[t]{2}{*}{$\mathrm{t}$} & \multirow[t]{2}{*}{ Sig. } & \multicolumn{2}{|c|}{$\begin{array}{l}\text { Collinearity } \\
\text { Statistics }\end{array}$} \\
\hline & B & $\begin{array}{l}\text { Std. } \\
\text { Error }\end{array}$ & & & & Tolerance & VIF \\
\hline 1 (Constant) & -.793 & .730 & & -1.087 & .283 & & \\
\hline PENDIDIKAN & .007 & .017 & .005 & .377 & .708 & .993 & 1.007 \\
\hline UMUR & .029 & .030 & .014 & .982 & .331 & .836 & 1.196 \\
\hline $\begin{array}{l}\text { PENGALAMAN } \\
\text { KERJA }\end{array}$ & 1.164 & .017 & .990 & 68.371 & .000 & .841 & 1.189 \\
\hline
\end{tabular}

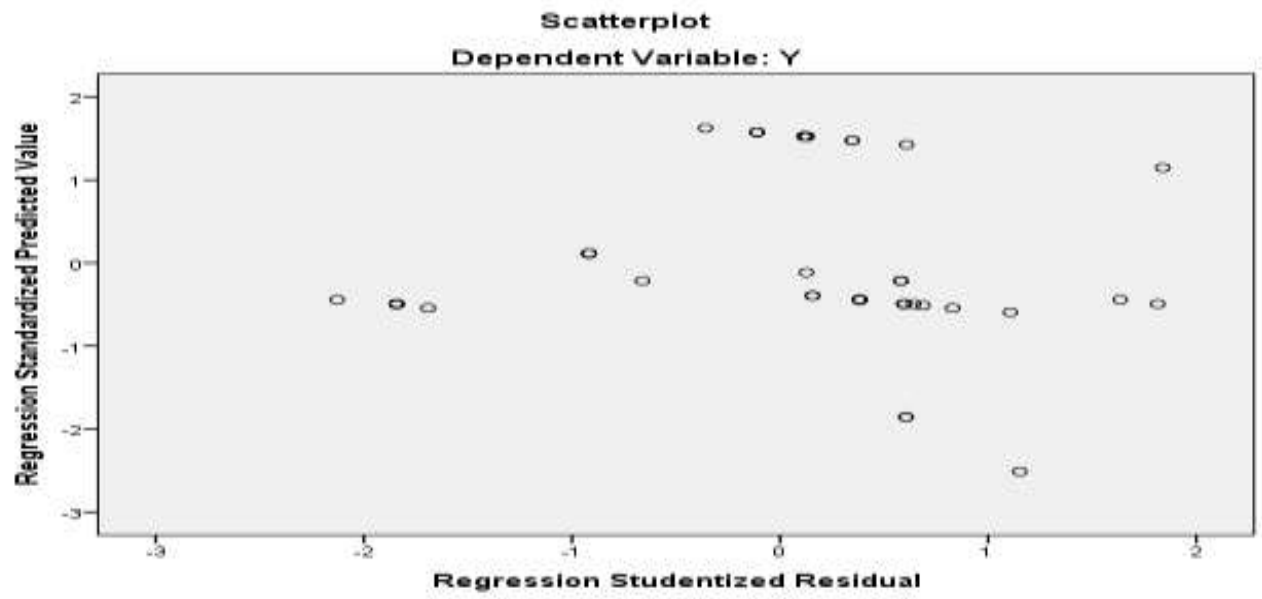

Gambar 1. Uji Heterokedastisitas 
Data pada gambar 1 menunjukkan titiktitik yang tidak membentuk pola apapun. Karena data pada scatterplot tidak beraturan, maka penelitian ini bebas masalah heterokedastisitas.

Langkah selanjutnya adalah uji normalitas. Uji normalitas bertujuan untuk menguji apakah dalam model regresi, variabel pengganggu atau residual memiliki distribusi normal. Distribusi normal membentuk suatu garis lurus diagonal, dan ploting data residual akan dibandingkan dengan garis diagonalnya. Jika distribusi data normal, maka garis yang menggambarkan data sebenarnya akan mengikut garis normalnya (Ferdinand,2012) Suatu penelitian dinyatakan terdisitribusi normal, jika residualnya bergerak seiring dengan kurva.

Kurva normal untuk uji normalitas dapat dilihat pada gambar 2. Karena residual data bergerak seiring dengan kurva normal, maka penelitian ini dinyatakan berdistribusi normal.

Selanjutnya dilakukan analisis regresi berganda untuk mengetahui pengaruh dari Pendidikan, umur, dan pengalaman kerja terhadap kinerja pegawai di Dinas Pekerjaan Umum, Penataan Ruang, Perumahan dan Kawasan Permukiman Kabupaten Kapuas.

\section{Uji $F$}

Untuk pengujian ini dihipotesiskan sebagai berikut :

Ho: $\beta_{1}=\beta_{2}=0$ Tidak ada pengaruh yang positif dan signifikan dari faktor pendidikan, umur, dan pengalaman kerja terhadap kinerja.

Ho: $\beta_{1}=\beta_{2} \neq 0$ Ada pengaruh yang positif dan signifikan faktor pendidikan, umur, dan pengalaman kerja terhadap kinerja.

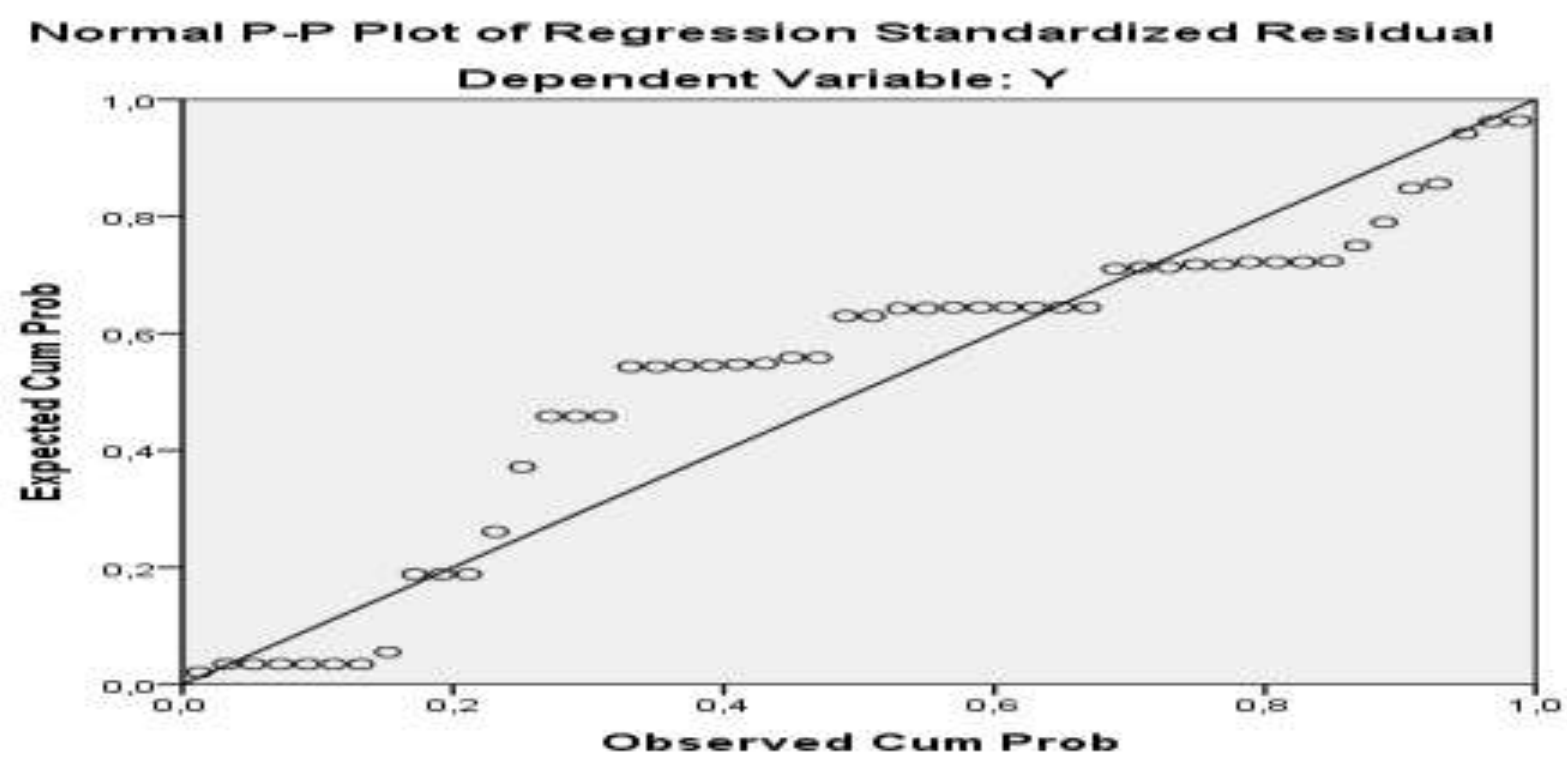

Gambar 2. Uji Normalitas

Tabel 2. Uji F

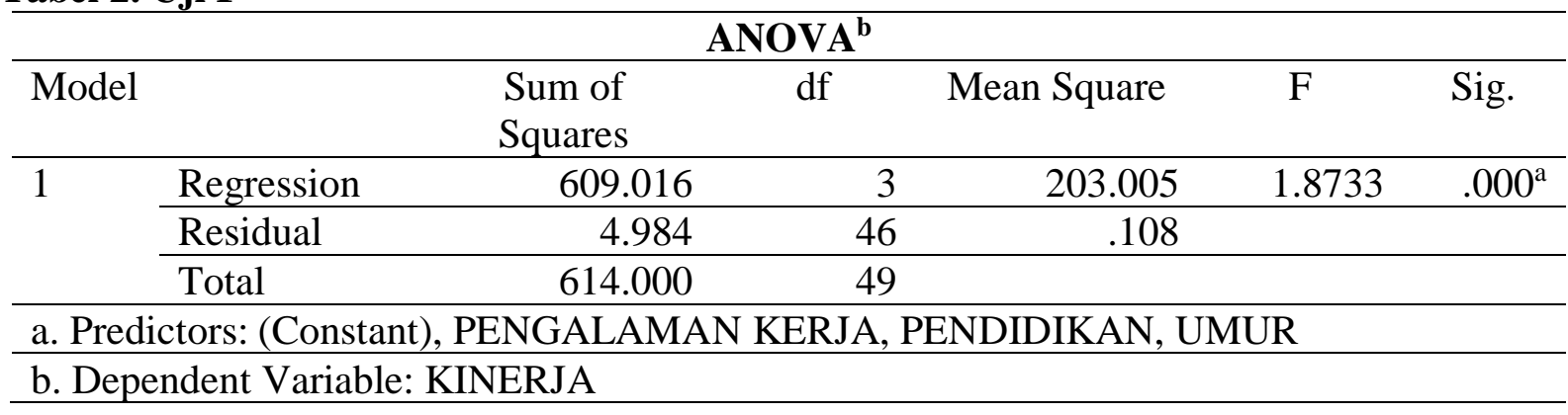


Dari uji Anova atau F test pada Tabel 2, didapat $\mathrm{F}$ hitung adalah 1.8733 dengan tingkat signifikansi 0,000 . Karena probabilitas $(0,000)$ jauh lebih kecil dari 0,005 maka model regresi bisa dipakai untuk mengetahui pengaruh terhadap kinerja. Atau bisa dikatakan pengalaman kerja, pendidikan dan umur bisa dikatakan secara bersama-sama berpengaruh terhadap kinerja. Secara simultan signifikan, nilai sig $<0,05$.

\section{Uji t}

Koefisien korelasi parsial menunjukkan pengaruh mana yang paling dominan dari variabel bebas yaitu faktor pendidikan, umur, dan pengalaman kerja terhadap kinerja Untuk pengujian ini dihipotesiskan sebagai berikut:

Ho : $\beta_{1}=0$ : Tidak ada pengaruh yang positif dan signifikan dari faktor pendidikan, umur, dan pengalaman kerja terhadap kinerja

$\mathrm{Ha}: \beta_{1}>0$ : ada pengaruh yang positif dari dari faktor pendidikan, umur, dan pengalaman kerja terhadap kinerja. Hasil nilai signifikansi pengujian (Sig.t) seperti ditunjukkan pada Tabel 3.

Dari data pada Tabel 3 kita dapat menggambarkan persamaan regresi sebagai berikut:

$\mathrm{Y}=-793+.007 \mathrm{X} 1+.029 \mathrm{X} 2+1.164 \mathrm{X} 3$

Dimana:

$\mathrm{Y}=$ Kinerja

$\mathrm{X} 1=$ Pendidikan

$\mathrm{X} 2=$ Umur

X3= Pengalaman Kerja

Konstanta sebesar -793

Koefisien Regresi X1 sebesar 0,007

Koefisien Regresi X2 sebesar 0,029

Koefisien Regresi X3 sebesar 1,164

Standardized Coefficients Beta pendidikan 0,005, umur 0,014 dan pengalaman kerja 0,990

Nilai Sig Pendidikan X1 0,780 Umur X2 0,331 Pengalaman Kerja X3 0,000

Tabel 3. Uji t

\begin{tabular}{|c|c|c|c|c|c|}
\hline \multicolumn{6}{|c|}{ Coefficients $^{\mathrm{a}}$} \\
\hline \multirow[t]{2}{*}{ Model } & \multicolumn{2}{|c|}{$\begin{array}{c}\text { Unstandardized } \\
\text { Coefficients }\end{array}$} & Standardized & $\mathrm{t}$ & Sig. \\
\hline & $B$ & Std. Error & Beta & & \\
\hline 1 (Constant) & -.793 & .730 & & -1.087 & .283 \\
\hline PENDIDIKAN & .007 & .017 & .005 & .377 & .708 \\
\hline UMUR & .029 & .030 & .014 & .982 & .331 \\
\hline $\begin{array}{l}\text { PENGALAMAN } \\
\text { KERJA }\end{array}$ & 1.164 & .017 & .990 & 68.371 & .000 \\
\hline
\end{tabular}

Tabel 4. Model Summary

\begin{tabular}{|c|c|c|c|c|}
\hline Model & $\mathrm{R}$ & R Square & $\begin{array}{l}\text { Adjusted R } \\
\text { Square }\end{array}$ & $\begin{array}{l}\text { Std. Error of the } \\
\text { Estimate }\end{array}$ \\
\hline 1 & $.996^{\mathrm{a}}$ & .992 & .991 & .32918 \\
\hline \multicolumn{5}{|c|}{ a. Predictors: (Constant), PENGALAMAN KERJA, PENDIDIKAN, UMUR } \\
\hline
\end{tabular}




\section{Koefisien Determinasi}

Dari tabel 4 terlihat nilai R Square sebesar 0.992, atau dengan kata lain 99,2\% artinya model penelitian mampu menjelaskan dari perubahan kinerja, sedangkan sisanya $(100 \%-99,2 \%=0,8 \%)$ dijelaskan oleh sebab-sebab lain.

Dari hasil pengujian data dapat diketahui Uji t untuk menguji signifikansi konstanta dan variabel dependen (Kinerja) terlihat pada angka sig (signifikansi atau besaran nilai probabilitas). Pengujian dilakukan dengan membandingkan nilai probality signifikansi dengan probality sebesar 5\% dalam arti $(\alpha=0.05)$. Pengaruh variabel faktor pendidikan terhadap kinerja. Pada tabel 4 memiliki nilai probality signifikansi yaitu lebih kecil dari 0,005, sehingga dapat disimpulkan faktor pendidikan tidak berpengaruh signifikan secara parsial dengan nilai sig 0,708. Pengaruh variabel umur terhadap kinerja, dengan nilai probality signifikansi yaitu lebih kecil dari 0,005 , dari hasil pengujian dapat diketahui variabel umur tidak berpengaruh signifikan dengan nilai sig 0,331.

Pengaruh variabel pengalaman kerja terhadap kinerja dengan nilai probality signifikansi yaitu lebih kecil dari 0,005. Diketahui penulis pengalaman kerja berpengaruh signifikan terhadap kinerja dengan nilai sig 0,000, karena dari hasil uji $\mathrm{t}$ diketahui pengalaman kerja nilai sig-nya lebih kecil dari 0,05 maka penulis menyatakan bahwa secara parsial pengalaman kerja berpengaruh signifikan terhadap kinerja. Dengan demikian hipotesis pertama variabel faktor pendidikan (X1), umur (X2) dan pengalaman kerja (X3) berpengaruh signifikan secara parsial terhadap kinerja aparatur sipil negara (asn) pada dinas pekerjaan umum penata ruang, perumahan dan kawasan permukiman Kabupaten Kapuas dalam penelitian ni ditolak, karena hanya pengalaman kerja yang berpengaruh signifikan terhadap kinerja.

Uji statistik $F$ atau simultan menunjukkan apakah semua variabel bebas yang dimasukkan dalam model mempunyai pengaruh secara bersama-sama terhadap variabel terikat. Pengujian dilakukan dengan signifikansi atau tidak, maka dugunakan probility sebesar 5\% dalam arti $(\alpha=0.05)$. Hasil penelitian dan dilakukan uji $\mathrm{F}$ dengan aplikasi SPSS. 16 di atas bahwa nilai probality signifikan secara simultan adalah lebih kecil dari 0,005 maka dapat disimpulkan secara simultan variabel pendidikan, umur dan pengalaman kerja berpengaruh signifikan terhadap kinerja Pegawai Dinas PU Kapuas.

Dari model summary terlihat nilai $\mathrm{R}$ Square sebesar 0,992\%. Artinya model penelitian mampu menjelaskan 99,2\%. dari perubahan kinerja. Sehingga hipotesis kedua variabel faktor pendidikan (X1), umur (X2) dan pengalaman kerja (X3) berpengaruh signifikan simultan terhadap kinerja aparatur sipil negara (asn) pada Dinas Pekerjaan Umum Penata Ruang Perumahaan dan Kawasan Permukiman Kabupaten Kapuas Kalimantan Tengah dapat diterima atau teruji.

Hipotesis ketiga variabel pendidikan adalah variabel yang berpengaruh dominan terhadap kinerja aparatur Dinas Pekerjaan Umum Penata Ruang Perumahaan dan Kawasan Permukiman Kabupaten Kapuas Kalimantan Tengah ternyata salah atau tidak diterima. Dari hasil pengujian di atas dapat diketahui bahwa sebanyak 50 Pegawai Dinas Pekerjaan Umum (PU) Kapuas Berdasarkan uji t Standardized Coefficients, nilai tertinggi ada pada variable X3 dengan nilai 990 dan nilai sig 0,000 , maka kesimpulan pada penelitian ini pengalaman kerja berpengaruh dominan terhadap kinerja aparatur Dinas Pekerjaan Umum Penata Ruang Perumahaan dan Kawasan Permukiman Kabupaten Kapuas Kalimantan Tengah.

\section{Kesimpulan}

Berdasarkan hasil analisis yang dilakukan dalam penelitian ini, berikut beberapa kesimpulan yang dapat diambil:

1. Faktor pendidikan, umur tidak berpengaruh signifikan sedangkan pengalaman kerja berpengaruh signifikan secara parsial terhadap kinerja aparatur sipil negara (ASN) pada Dinas Pekerjaan Umum Penata Ruang Perumahan dan Kawasan Pemukiman Kabupaten Kapuas Kalimantan Tengah. 
2. Faktor pendidikan, umur dan pengalaman kerja secara simultan berpengaruh signifikan terhadap kinerja aparatur sipil negara (ASN) pada Dinas Pekerjaan Umum Penata Ruang Perumahan dan Kawasan Pemukiman Kabupaten Kapuas Kalimantan Tengah.

3. Berdasarkan hasil penelitian pengalaman kerja berpengaruh dominan terhadap kinerja pegawai aparatur sipil negara (ASN) pada Dinas Pekerjaan Umum Penata Ruang Perumahan dan Kawasan Pemukiman Kabupaten Kapuas Kalimantan Tengah.

\section{DAFTAR PUSTAKA}

Arikunto, Suharsimi. 2006. Prosedur Penelitian; SuatuPendekatanPraktek. Edisi Revisi VI. Penerbit Rineka Cipta Jakarta.

Amron, 2010, Pengetahuan Dan Produktivitas Skill Tenaga Kerja, Jakarta, Indonesia

Asri, (2011;131), Kinerja Karyawan, Jakarta, Indonesia

Dessler, Gerry, 1992. Manajemen Personalia, Teknik Personalia, Teknik dan Konsep Modern. Erlangga. Jakarta.

Ferdinan, 2012, Manajemen Sumber Daya Manusia. Jakarta, Erlangga.

Fadhilah Rahmawati, dkk, 2011, Evektivitas Pengalokasian Sumber Daya Manusia, Jakarta, Indonesia

Ghojali, Imam. 2016. Aflikasi Analisis Multivariete dengan Perogram IBM SPSS 23. Cetakan Kedelapan. Badan Penerbit Universitas Diponegoro, Semarang.

Handoko, Hani T. Dan Soegito Reksohadiprodjo. 1996. Manajemen Sumber Daa Manusia. Yogyakarta : Liberty

Henry Simamora, 1995, Kinerja. Jakarta, Indonesia

Haderson, 2010, Manajemen Sumber Daya Manusia. Jakarta, Salemba Empat

Hoetomo, 2015, Upaya Pengawasan Dalam Meningkatkan Kinerja Karyawan

Juni Dwi Astono, 2013, Pengaruh Tingkat Pendidikan, Pengalaman Kerja, Dan
Gaya Kepemimpinan Terhadap Kinerja Melalui Disiplin Kerja Karyawan Dinas Pekerjaan Umum Provinsi Kalimantan Tengah

Koesoemato Setyonegoro, 2013, TINGKAT PENDIDIKAN DAN PELATIHAN

MJ Lavenged, 1980, Pengetahuan Dan Produktivitas Skill Tenaga Kerja, Jakarta, Indonesia

Munally, 2011-385, Kinerja Dan Prestasi Kerja, Jakarta, Indonesia.

Mangkunegara, 2011. Manajemen Sumber Daya Manusia. Jakarta, Bumi Aksara

Manullang, M 1995. Azas-azas Manjemen. Jakarta : Ghalia Indonesia.

Nurwatun, 1998, Dasar-Dasar Manajemen, Cetakan kesembilan, Ghalia Indonesia, Jakarta

Nitisemito, 2010: 86; dalam Rofi, 2012, Pengelaman Kerja, Jakarta, Indonesia

Notoatmojo, 2013, Leadership, Jakarta, Indonesia

Payman. 2001, Kriteria Mempertahankan Prestasi Kerja, Jakarta, Indonesia.

Prawirosentono, 2011, Kinerja Pegawai, Jakarta, Indonesia.

Rusnama, 2006, Kedisiplinan Karyawan Dalam Meningkatkan Kinerja Perusahaan, Jakarta, Indonesia

Rika Wulanda, 2013, PENGARUH TINGKAT PENDIDIKAN DAN PELATIHAN, MOTIVASI DAN BUDAYA ORGANISASI TERHADAP KINERJA PEGAWAI NEGERI SIPIL SEKRETARIAT DAERAH KABUPATEN WAKATOBI

Suharjo, 2007, Program Kerja Perusahaan, Jakarta, Indonesia

Sugiono. 2007. MeyodePenelitianBisnis. Cetakan Kesepuluh. CV. Alfabeta Bandung.

Sudianto, 2008, Manajemen Sumber Daya Manusia. Jakarta, Bumi Aksara

Sarwono, 2008, Sistem Penilaian Kinerja Karyawan, Jakarta, Indonesia

Suwanto, 2011, Manajemen Sumber Daya Manusia, Jakarta, Indonesia

Todaro, 2010, Nilai-Nilai Kultural Dan Pembangunan Manusia, Jakarta, Indonesia. 